shikimic acid or whether the reduction of the two compounds follows separate routes. The results show, however, that quinic acid and shikimic acid are interconvertible. In the scheme studied by Davis (1955) with Escherichia coli mutants it appears that quinic acid is not in the direct sequence leading from carbohydrate through shikimic acid to the aromatic metabolites. In this scheme the precursors of shikimic acid are 5-dehydroquinic acid and 5-dehydroshikimic acid. In the present tests it has not been possible to demonstrate the formation of either of the latter two compounds. The possible participation of quinic acid in a sequence leading to aromatization is, however, not excluded since in the wild-type Aerobacter aerogenes quinic acid is a precursor of 5-dehydroquinic acid. In the lactic acid bacterium investigated there is as yet no evidence to suggest the role of shikimic acid as a precursor of aromatic amino acids.

\section{SUMMARY}

1. Growing and resting cells of an organism occurring in cider, Lactobacillus pastorianus var. quinicus, are capable of converting quinic and shikimic acids into dihydroshikimic acid.
2. The quinic acid to shikimic acid step is reversible.

The authors are indebted to Professor Wilson Baker, F.R.S., and Dr W. D. Ollis for helpful discussions on the configuration of dihydroshikimic acid. We also wish to thank Dr B. D. Davis and Professor Grewe for gifts of 5-dehydroshikimic acid and the isopropylidene derivative of the lactone of dihydroshikimic acid respectively.

\section{REFERENCES}

Carr, J. G. (1952). Rep. agric. hort. Res. Sta., Bristol, p. 144.

Carr, J. G., Phillips, J. D. (the late), Pollard, A., Whiting, G. C. \& Williams, A. H. (1954). Chem. \& Ind. p. 1515.

Cartwright, R. A. \& Roberts, E. A. H. (1955). Chem. \& Ind. p. 230 .

Davis, B. D. (1955). A Symposium on Amino Acid Metabolism, p. 779. Ed. by McElroy, W. D. \& Glass, B. Baltimore: The Johns Hopkins Press.

Grewe, R. \& Lorenzen, W. (1953). Chem. Ber. 86, 928.

Hulme, A. C. (1951). J. exp. Bot. 2, 298.

Phillips, J. D. (the late), Pollard, A. \& Whiting, G. C. (1956). J. Sci. Fd Agric. 7, 31.

Stark, J. B., Goodban, A. E. \& Owens, H. S. (1951). Analyt. Chem. 23, 413.

Weiss, U., Davis, B. D. \& Mingioli, E. S. (1953). J. Amer. chem. Soc. 75, 5572.

\title{
Studies on the Carbohydrate Metabolism of Skin
}

\author{
By C. N. D. CRUICKSHANK, M. D. TROTTER AND J. R. COOPER \\ Medical Research Council Unit for Research on the Experimental Pathology of the Skin, \\ University of Birmingham
}

(Received 10 September 1956)

One of the classical methods of determining the metabolic pathways in a tissue is the investigation of the effects of various possible substrates upon the oxygen uptake in vitro. This method is open to the criticisms that some substances may not adequately penetrate the cell membrane (particularly if tissue slices are used) and that unknown factors may be present in vivo but absent from the in vitro preparation. Nevertheless, positive findings may be regarded as reliable provided that catalytic or hormonal effects are excluded. This investigation is concerned with the metabolism of glucose and fructose and with the effects of various possible intermediate metabolites upon the respiration of skin slices in vitro.

\section{MATERIALS AND METHODS}

Oxygen uptake was measured by means of the differential capillary respirometer designed by Cruickshank (1954) and used for a previous investigation of the glucose and lactic acid metabolism of skin (Cruickshank \& 'Trotter, 1956). The skin slices were cut free-hand from the dorsum of the guineapig ear, and, to minimize animal variation, each experiment was designed to include its own control and to permit of statistical evaluation. The control medium consisted of Krebs-Ringer phosphate (Field, 1948) and for experiments lasting $24 \mathrm{hr}$. streptomycin sulphate was added to a final concentration of $50 \mu \mathrm{g} . / \mathrm{ml}$. Substrates (either sodium salts or free acids) were prepared in solutions ten times more concentrated than required, adjusted to $\mathrm{pH} 7 \cdot 4$ with $\mathrm{NaOH}$ where necessary and sterilized by boiling or Seitz filtration. The potassium salt of glucose 1-phosphate was used. The substrates were added to the basic medium as $10 \%$ of the final volume to give the required concentration. All experiments were carried out in an atmosphere of air and at $37^{\circ}$. Respiration and hexose utilization rates were expressed in relation to wet weight of tissue.

Glucose analyses were carried out by the method of Somogyi (1952) and Nelson (1944), and fructose estimations by the method of Roe (1934). Lactate was estimated by the method of Barker \& Summerson (1941). 


\section{RESULTS} Effect of concentration on the metabolism of
glucose and fructose over $5 \mathrm{hr}$.

The effects of various concentrations of glucose on oxygen uptake, glucose utilization and lactic acid production are shown in Table 1 . The concentration of glucose does not affect the oxygen uptake within the range tested, nor does it greatly affect the amount of glucose used except at the lowest concentration, where utilization is lower. Included in Table 1 is the amount of glucose which could theoretically be used if all the oxygen uptake was consumed in the complete oxidation of hexose. While this is unlikely to be wholly true, the measure will be useful in examining the possible fate of added hexose. As the respiration is constant it follows that the assumed hexose oxidized is constant. The lactic acid production behaves similarly to the glucose utilization; the sum of the lactic acid production and the calculated amount of glucose oxidized corresponds roughly with the total glucose utilization. It will be seen that the respiration in the presence of glucose is some $20 \%$ greater than the residual and that only a very small amount of lactic acid was found in the absence of substrate.

The effects of various concentrations of fructose are shown in Table 2 . In contrast with glucose, the oxygen uptake and the fructose utilization increase with the concentration of the fructose. Only traces of lactic acid were produced. Assuming the oxygen uptake to be used for the oxidation of hexose, there

Table 1. Effect of concentration of glucose on respiration and glucose utilization of skin slices

Results are expressed as the mean of four experiments, with standard error of the mean. Incubation was for $5 \mathrm{hr}$. Results refer to moist weight of skin.

$\begin{array}{lc}\begin{array}{c}\text { Concn. } \\ (\mathrm{M})\end{array} & \begin{array}{c}\mathrm{O}_{2} \text { uptake } \\ (\mu \mathrm{l} . / \mathrm{mg} . / \mathrm{hr} .)\end{array} \\ 0 & 0 \cdot 84 \pm 0.04 \\ 0.002 & 1 \cdot 10 \pm 0.05 \\ 0.005 & 0.98 \pm 0.08 \\ 0.01 & 1 \cdot 00 \pm 0.08 \\ 0.02 & 0.97 \pm 0.06\end{array}$

$\begin{gathered}\text { Glucose } \\ \text { utilization } \\ (\mu \mathrm{g} \cdot / \mathrm{mg} \cdot / \mathrm{hr} .)\end{gathered}$
-
$2 \cdot 26 \pm 0 \cdot 26$
$\mathbf{3} \cdot 54 \pm 0 \cdot 20$
$\mathbf{3} \cdot 84 \pm 0 \cdot 27$
$\mathbf{4 \cdot 4 4} \pm 0 \cdot 30$

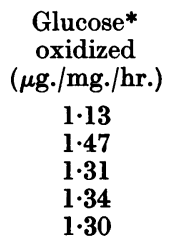

Lactic acid
produced
$(\mu \mathrm{g} . / \mathrm{mg} \cdot / \mathrm{hr}$.
$0 \cdot 44 \pm 0 \cdot 18$
$1 \cdot 19 \pm 0 \cdot 26$
$2 \cdot 68 \pm 0 \cdot 06$
$2 \cdot 52 \pm 0 \cdot 01$
$2 \cdot 33 \pm 0 \cdot 10$

* Assuming that $\mathrm{O}_{2}$ uptake is utilized entirely for the oxidation of glucose to $\mathrm{CO}_{2}$.

Table 2. Effect of concentration of fructose on respiration and fructose utilization of skin slices

Results are expressed as the mean of four experiments, with standard error of the mean. Incubation was for 5 hr. The results refer to moist weight of skin.

$\begin{array}{cccc}\begin{array}{c}\text { Concn. } \\ (\mathrm{M})\end{array} & \begin{array}{c}\mathrm{O}_{2} \text { uptake } \\ (\mu \mathrm{l} / \mathrm{mg} . / \mathrm{hr} .)\end{array} & \begin{array}{c}\text { Fructose utilized } \\ (\mu \mathrm{g} . / \mathrm{mg} . / \mathrm{hr} .)\end{array} & \begin{array}{c}\text { Possible* hexose } \\ \text { utilization } \\ (\mu \mathrm{g} . / \mathrm{mg} . / \mathrm{hr} .)\end{array} \\ 0 & 0 \cdot 61 \pm 0 \cdot 12 & - & 0.82 \\ 0.002 & 0 \cdot 81 \pm 0.03 & 0.26 \pm 0 \cdot 06 & 1.09 \\ 0.005 & 0 \cdot 88 \pm 0.05 & 0.58 \pm 0 \cdot 10 & 1 \cdot 18 \\ 0.01 & 0 \cdot 89 \pm 0.04 & 0.91 \pm 0 \cdot 10 & 1.19 \\ 0.02 & 1.01 \pm 0.04 & 1 \cdot 87 \pm 0 \cdot 10 & 1.35\end{array}$

* Assuming that $\mathrm{O}_{2}$ uptake is utilized entirely for the oxidation of hexose to $\mathrm{CO}_{2}$.

Table 3. Effect of glucose on fructose utilization

Results are expressed as the mean of six experiments, with standard error of the mean. Incubation was for $5 \mathrm{hr}$. The results refer to moist weight of skin.

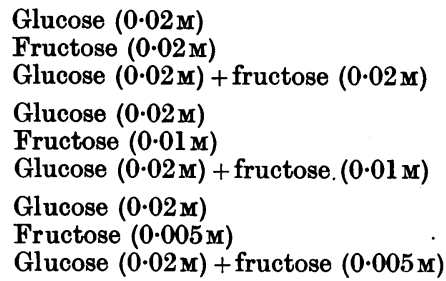

$\mathrm{O}_{2}$ uptake
$(\mu \mathrm{l} . / \mathrm{mg} . / \mathrm{hr}$.
$0.98 \pm 0.04$
$1 \cdot 04 \pm 0.06$
$1 \cdot 02 \pm 0.05$
$0.92 \pm 0.01$
$0.94 \pm 0.01$
$1 \cdot 00 \pm 0.01$
$1 \cdot 12 \pm 0.15$
$1 \cdot 01 \pm 0.03$
$1 \cdot 17 \pm 0.03$

$\begin{gathered}\text { Glucose } \\ \text { utilized } \\ (\mu \mathrm{g} . / \mathrm{mg} . / \mathrm{hr} .)\end{gathered}$
$4 \cdot 35 \pm 0 \cdot 37$
3.58
$3 \cdot 46 \pm 0 \cdot 11$
$3 \cdot 76$
$4 \cdot 11 \pm 0 \cdot 24$
$4 \cdot 21$

$\begin{gathered}\text { Fructose } \\ \text { utilized } \\ (\mu \mathrm{g} . / \mathrm{mg} . / \mathrm{hr} .)\end{gathered}$
-
$1 \cdot 65 \pm 0 \cdot 12$
$1 \cdot 11 \pm 0.08$
-
$0 \cdot 94 \pm 0.03$
$0 \cdot 67 \pm 0.03$
-
$0.42 \pm 0.03$
$0.28 \pm 0.04$

\begin{tabular}{|c|}
\hline $\begin{array}{l}\text { Total hexose } \\
\text { utilized } \\
\text { ( } \mu \mathrm{g} . / \mathrm{mg} . / \mathrm{hr} .)\end{array}$ \\
\hline $\begin{array}{l}4 \cdot 35 \\
1 \cdot 65 \\
4 \cdot 69 \pm 0 \cdot 03\end{array}$ \\
\hline $\begin{array}{l}3 \cdot 46 \\
0.94 \\
4 \cdot 43 \pm 0.44\end{array}$ \\
\hline $\begin{array}{l}4 \cdot 11 \\
0 \cdot 42 \\
4 \cdot 49 \pm 0 \cdot 25\end{array}$ \\
\hline
\end{tabular}

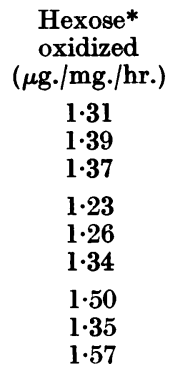

* Assuming that $\mathrm{O}_{2}$ uptake is utilized entirely for the oxidation of hexose. 
was insufficient fructose used to account for the respiration except at the highest concentration, and consequently endogenous substrate must have been used.

Table 3 shows the effects of glucose on fructose utilization. In each group of experiments the oxygen uptake and hexose utilization of glucose, fructose and mixtures of these substances are compared. Glucose was used at a concentration of $0.02 \mathrm{M}$ throughout and fructose was used in concentrations of $0.02,0.01$ and $0.005 \mathrm{M}$ in the respective groups. Whereas the presence of fructose does not appear to affect the glucose utilization, the fructose utilization in the presence of glucose is reduced by about onethird. The total hexose utilization in the presence of both substrates is increased, although there is little or no increase in the amount oxidized.

\section{Effect of possible metabolites on respiration}

The respiration of skin slices in media containing various possible metabolites was compared with the residual respiration of slices from the same animal in
Krebs-Ringer phosphate. Each compound was tested initially at $0.02 \mathrm{M}$-concentration and those compounds giving little or no effect were also tested at $0.04 \mathrm{~m}$-concentration. The experiments were carried out over $24 \mathrm{hr}$. and observations were made at 0-1, 4-5 and 22-24 hr. (Table 4). During this period the mean residual respiration fell from $0.80 \mu \mathrm{l} . / \mathrm{mg} . / \mathrm{hr}$. at $0-1 \mathrm{hr}$. to $0.58 \mu \mathrm{l} . / \mathrm{mg} . / \mathrm{hr}$. at 4-5 hr. and to $0.26 \mu \mathrm{l} . / \mathrm{mg}$. $/ \mathrm{hr}$. at $22-24 \mathrm{hr}$.

Stimulation of respiration in the first hour was caused by fructose, lactate, pyruvate, acetate, citrate, succinate and oxaloacetate in concentrations of $0.02 \mathrm{M}$. In this series of experiments glucose produced no initial increase of respiration. Other experiments have shown that the immediate effect of glucose is variable and often slight. Of the substances listed above, the effect of acetate was the least; the others produced an increase of 25-30\%. Glucose 1-phosphate caused a significant decrease of respiration. No effect was given by $\alpha$-oxoglutarate, fumarate or malate at $0.02 \mathrm{M}$-concentration. When these three substances were tested in $0.04 \mathrm{M}$ -

Table 4. Effect of added metabolites on the respiration of skin

\begin{tabular}{|c|c|c|c|c|c|c|c|c|}
\hline Substrate & $\begin{array}{c}\begin{array}{c}\text { No. of } \\
\text { experiments }\end{array} \\
\text { ent }\end{array}$ & $\begin{array}{l}\text { Substrate } \\
\text { concn. } \\
\text { (M) }\end{array}$ & $\begin{array}{c}\mathrm{O}_{2} \text { uptake } \\
(0-1 \mathrm{hr} .) \\
(\mu \mathrm{l} . / \mathrm{mg} . / \mathrm{hr} .)\end{array}$ & Diff. & $\begin{array}{c}\mathrm{O}_{2} \text { uptake } \\
(4-5 \mathrm{hr} .) \\
(\mu \mathrm{l} . / \mathrm{mg} . / \mathrm{hr} .)\end{array}$ & Diff. & $\begin{array}{c}\mathrm{O}_{2} \text { uptake } \\
(22-24 \mathrm{hr} .) \\
(\mu \mathrm{l} . / \mathrm{mg} . / \mathrm{hr} .)\end{array}$ & Diff. \\
\hline $\begin{array}{l}\text { None } \\
\text { Glucose }\end{array}$ & $\overline{8}$ & $\overline{0.02}$ & $\begin{array}{l}0 \cdot 74 \\
0.79\end{array}$ & $0 \cdot 05^{*}$ & $\begin{array}{l}0.58 \\
0.78\end{array}$ & 0.20 & $\begin{array}{l}0 \cdot 26 \\
0.57\end{array}$ & 0.31 \\
\hline $\begin{array}{l}\text { None } \\
\text { Fructose }\end{array}$ & $\overline{8}$ & $\overline{0.02}$ & $\begin{array}{l}0 \cdot 77 \\
0.97\end{array}$ & $0 \cdot 20$ & $\begin{array}{l}0.53 \\
1.00\end{array}$ & 0.47 & $\begin{array}{l}0 \cdot 20 \\
0 \cdot 72\end{array}$ & 0.52 \\
\hline $\begin{array}{l}\text { None } \\
\text { Glucose 1-phosphate }\end{array}$ & $\overline{8}$ & $\overline{0.02}$ & $\begin{array}{l}0 \cdot 87 \\
0 \cdot 74\end{array}$ & $-0 \cdot 13$ & $\begin{array}{l}0 \cdot 60 \\
0 \cdot 64\end{array}$ & $0.04^{*}$ & $\begin{array}{l}0.25 \\
0 \cdot 41\end{array}$ & $0 \cdot 16$ \\
\hline $\begin{array}{l}\text { None } \\
\text { Lactate }\end{array}$ & $\overline{8}$ & $\overline{0.02}$ & $\begin{array}{l}0 \cdot 87 \\
1 \cdot 12\end{array}$ & 0.25 & $\begin{array}{l}0 \cdot 60 \\
1 \cdot 13\end{array}$ & 0.53 & $\begin{array}{l}0 \cdot 24 \\
1 \cdot 13\end{array}$ & 0.89 \\
\hline $\begin{array}{l}\text { None } \\
\text { Pyruvate }\end{array}$ & $\overline{8}$ & $\overline{0.02}$ & $\begin{array}{l}0.82 \\
1.06\end{array}$ & 0.24 & $\begin{array}{l}0 \cdot 59 \\
1 \cdot 18\end{array}$ & 0.59 & $\begin{array}{l}0.28 \\
0.84\end{array}$ & 0.56 \\
\hline $\begin{array}{l}\text { None } \\
\text { Acetate }\end{array}$ & $\overline{12}$ & $\overline{0.02}$ & $\begin{array}{l}0 \cdot 77 \\
0 \cdot 84\end{array}$ & 0.07 & $\begin{array}{l}0.56 \\
0 \cdot 71\end{array}$ & $0 \cdot 15$ & $\begin{array}{l}0 \cdot 23 \\
0 \cdot 35\end{array}$ & 0.12 \\
\hline $\begin{array}{l}\text { None } \\
\text { Citrate }\end{array}$ & $\overline{16}$ & $\overline{0.02}$ & $\begin{array}{l}0 \cdot 70 \\
0 \cdot 87\end{array}$ & 0.17 & $\begin{array}{l}0 \cdot 54 \\
0 \cdot 60\end{array}$ & $0.06^{*}$ & $\begin{array}{l}0 \cdot 24 \\
0 \cdot 18\end{array}$ & $-0.06^{*}$ \\
\hline $\begin{array}{l}\text { None } \\
\alpha \text {-Oxoglutarate }\end{array}$ & $\overline{12}$ & $\overline{0.02}$ & $\begin{array}{l}0.89 \\
0.89\end{array}$ & $0^{*}$ & $\begin{array}{l}0.59 \\
0.62\end{array}$ & $0.03^{*}$ & $\begin{array}{l}0 \cdot 24 \\
0 \cdot 28\end{array}$ & $0 \cdot 04^{*}$ \\
\hline $\begin{array}{l}\text { None } \\
\alpha \text {-Oxoglutarate }\end{array}$ & $\overline{8}$ & $\overline{0.04}$ & $\begin{array}{l}0.82 \\
0.91\end{array}$ & $0.03^{*}$ & $\begin{array}{l}0.55 \\
0.65\end{array}$ & $0 \cdot 10^{*}$ & $\begin{array}{l}0 \cdot 17 \\
0 \cdot 19\end{array}$ & $0.02^{*}$ \\
\hline $\begin{array}{l}\text { None } \\
\text { Succinate }\end{array}$ & $\overline{8}$ & $\overline{0.02}$ & $\begin{array}{l}0 \cdot 82 \\
1 \cdot 03\end{array}$ & $0 \cdot 21$ & $\begin{array}{l}0.64 \\
0.81\end{array}$ & 0.17 & $\begin{array}{l}0 \cdot 36 \\
0 \cdot 57\end{array}$ & 0.21 \\
\hline $\begin{array}{l}\text { None } \\
\text { Fumarate }\end{array}$ & $\overline{8}$ & $\overline{0.02}$ & $\begin{array}{l}0 \cdot 83 \\
0 \cdot 88\end{array}$ & $0.05^{*}$ & $\begin{array}{l}0.59 \\
0.61\end{array}$ & $0.02^{*}$ & $\begin{array}{l}0 \cdot 26 \\
0 \cdot 37\end{array}$ & $0 \cdot 11^{*}$ \\
\hline $\begin{array}{l}\text { None } \\
\text { Fumarate }\end{array}$ & $\overline{8}$ & $\overline{0.04}$ & $\begin{array}{l}0 \cdot 74 \\
0 \cdot 93\end{array}$ & $0 \cdot 19$ & $\begin{array}{l}0.53 \\
0.65\end{array}$ & 0.12 & $\begin{array}{l}0 \cdot 19 \\
0 \cdot 16\end{array}$ & $-0.03^{*}$ \\
\hline $\begin{array}{l}\text { None } \\
\text { Malate }\end{array}$ & $\overline{8}$ & $\overline{0.02}$ & $\begin{array}{l}0 \cdot 77 \\
0 \cdot 78\end{array}$ & $0.01 *$ & $\begin{array}{l}0 \cdot 60 \\
0 \cdot 60\end{array}$ & $0^{*}$ & $\begin{array}{l}0 \cdot 24 \\
0 \cdot 37\end{array}$ & $0 \cdot 13$ \\
\hline $\begin{array}{l}\text { None } \\
\text { Malate }\end{array}$ & $\overline{8}$ & $\overline{0.04}$ & $\begin{array}{l}0 \cdot 72 \\
0 \cdot 83\end{array}$ & $0 \cdot 11$ & $\begin{array}{l}0.55 \\
0.63\end{array}$ & 0.08 & $\begin{array}{l}0 \cdot 26 \\
0 \cdot 32\end{array}$ & 0.06 \\
\hline $\begin{array}{l}\text { None } \\
\text { Oxaloacetate }\end{array}$ & $\overline{8}$ & $\overline{0.02}$ & $\begin{array}{l}0 \cdot 70 \\
0.93\end{array}$ & $0 \cdot 23$ & $\begin{array}{l}0.52 \\
0.92\end{array}$ & $0 \cdot 40$ & $\begin{array}{l}0 \cdot 24 \\
0 \cdot 03\end{array}$ & $-0 \cdot 21$ \\
\hline
\end{tabular}

* These differences are not statistically significant $(P>0.05)$. 
concentrations, however, fumarate and malate both gave rise to stimulation in the first hour. $\alpha$-Oxoglutarate caused a small but not statistically significant rise in respiration.

Between 4 and $5 \mathrm{hr}$., the difference in respiration between the control skin and that in glucose, fructose, lactate, pyruvate, acetate and oxaloacetate was greater. With the exception of acetate, which caused a small fall in respiration, these substances maintained the initial high rate, whereas the respiration of the control slices had fallen by about $27 \%$.

Glucose 1-phosphate, which had caused an initial depression, became level with the control between 4 and $5 \mathrm{hr}$. Succinate still gave rise to increased oxygen uptake but at a level lower than in the first hour. $\alpha$-Oxoglutarate, fumarate and malate showed no effect at $0.02 \mathrm{M}$-concentration, but at $0.04 \mathrm{M}$ the two latter substances caused increased oxygen uptake. The stimulating effect of citrate, apparent at $0-1 \mathrm{hr}$., had decreased by the fifth hr.

At $24 \mathrm{hr}$. the outstanding substrates were glucose, fructose, lactate and pyruvate, which maintained respiration very near the original level. Acetate and succinate still gave increased respiratory rates. Citrate, $\alpha$-oxoglutarate and fumarate $(0.02 \mathrm{M})$ were without effect. Oxaloacetate, which earlier caused stimulation, now caused depression, and glucose 1-phosphate, which had depressed respiration in the first hour, now caused slight stimulation. Malate $(0.02 \mathrm{M})$, which had no effect in the first $5 \mathrm{hr}$., caused increased respiration, as did malate $(0 \cdot 04 \mathrm{M})$ and fumarate $(0.04 \mathrm{M})$.

\section{DISCUSSION}

The rate of glucose utilization in the present series of experiments with Krebs-Ringer phosphate medium differs from that previously described (Cruickshank \& Trotter, 1956), where $50 \%$ serum was included in the medium. With a glucose concentration of $0.02 \mathrm{M}$ the utilization rate of about $4 \mu \mathrm{g} . / \mathrm{mg}$./hr. is less than one-half of that found in the presence of serum. The lactic acid production is similarly reduced, but the oxygen consumption is reduced only slightly. In a simple medium the amount of glucose oxidized and lactic acid produced account for all the glucose used, whereas in the presence of serum $10-30 \%$ could not be accounted for satisfactorily. The effect of serum in increasing the glucose utilization of the rat diaphragm has been previously observed. This phenomenon has been discussed by Randle (1954) and attributed in part to the presence of insulin.

The constant rate of glucose utilization over a range of concentrations is consistent with the view that the transfer of glucose across the cell membrane is actively controlled. The variation of fructose utilization with concentration suggests that fructose passes into the cell by simple diffusion. Whereas glucose utilization is unaffected by the presence of fructose, the amount of fructose used is appreciably reduced. In brain tissue, where no specific fructokinase has been demonstrated, glucose totally suppresses fructose utilization (Slein, Cori \& Cori, 1950), but in muscle, where a fructokinase has been demonstrated, fructose utilization at a reduced rate persists in the presence of glucose (Reynold \& Horn, 1955). It is therefore probable that both glucokinase and fructokinase exist in skin, a conclusion reached on other grounds by Bullough (1954b).

In Tables 1 and 2 we have calculated the theoretical amount of hexose which could be fully oxidized by the observed oxygen uptake. Since we have shown that glucose and fructose only slightly increase the oxygen uptake over the residual level it could be further assumed that the oxidation of endogenous substrate is inhibited to a certain extent. Glucose might conceivably inhibit completely the use of endogenous substrate at all concentrations, but it is clear that fructose could do so only at the highest concentration. While it is likely therefore that inhibition of the oxidation of endogenous substrate occurs, the extent of this is not determinable in the present series of experiments.

It has been shown that all the metabolites so far tested, with the exception of $\alpha$-oxoglutarate, have some effect on the respiration of skin at some time during the $24 \mathrm{hr}$. of observation. Our experiments permit the analysis of two separate properties, the ability to cause stimulation, i.e. an increase of respiration over the residual respiratory rate during the first hour, and the ability to maintain respiration over the subsequent period during which the respiration falls in the absence of substrate. By making observations over the longer period we have been able to minimize the difficulties caused by the high residual respiration of skin. The only substances of those tested which were capable of both stimulating and maintaining respiration over $24 \mathrm{hr}$. were glucose, fructose, lactate and pyruvate. Of these glucose was least effective, and the efficiency of lactate in this respect was striking.

The stimulating effect of glucose, pyruvate, lactate and succinate has been described by Thompson (1946) and by Barron, Meyer \& Miller (1948). Our experiments showed that succinate, malate and, to a lesser extent, acetate caused initial stimulation but failed to prevent a gradual fall over the subsequent $24 \mathrm{hr}$. The stimulating effects of oxaloacetate and fumarate declined even faster. The relative failure of these intermediates suggests that some end product of the glycolytic process, possibly a two-carbon fragment, is required for the adequate maintenance of the oxidative cycle for $24 \mathrm{hr}$. It is of interest that Bullough (1954a) found that, of a series of substances in- 
cluding citrate, $\alpha$-oxoglutarate, succinate, fumarate and malate, only glucose, fructose, lactate and pyruvate produced maximal mitotic activity over $4 \mathrm{hr}$. in mouse-ear skin in vitro.

The effects of glucose 1-phosphate are difficult to interpret without further experiments to determine the fate of the compound.

Barron et al. (1948) and Griesemer \& Gould (1954) found citrate to have no effect upon skin respiration. Barron et al. also failed to demonstrate isocitric dehydrogenase in skin and found no stimulation on the addition of $\alpha$-oxoglutarate. On these grounds they suggested that the citric acid cycle in its classical form did not operate in skin. Our results, which show a sharp contrast between the obvious usage of succinate, fumarate, malate and oxaloacetate and the transient usage of citrate and nonutilization of $\alpha$-oxoglutarate, are consistent with their findings, but the evidence is as yet insufficient to conclude that skin differs in its oxidative processes from the majority of other tissues.

\section{SUMMARY}

1. The respiration and glucose utilization of skin of the guinea-pig ear in vitro are unaffected by the glucose concentration within the range $0.005-$ $0.02 \mathrm{M}$.

2. The respiration and fructose utilization increase as the fructose concentration is increased.

3. In glucose-fructose mixtures the utilization of fructose is reduced, the glucose utilization is unaffected and the total hexose utilization thus increases. This is not reflected in an increased respiration rate.

4. In the absence of serum the glucose utilization is only about one-half of that occurring in the presence of serum, and the respiration is only slightly reduced; the sum of lactic acid produced and the calculated glucose oxidized equals the observed glucose utilized.
5. Glucose, fructose, lactate and pyruvate stimulate respiration and maintain a relatively high respiration rate for $24 \mathrm{hr}$.

6. Succinate, malate and acetate stimulate respiration but permit a gradual decline over $24 \mathrm{hr}$.

7. Oxaloacetate maintains respiration for $5 \mathrm{hr}$. only, subsequently becoming toxic; fumarate also stimulates respiration initially but its effect declines between 5 and $24 \mathrm{hr}$.

8. Citrate causes transitory stimulation in the first hour and $\alpha$-oxoglutarate is without effect.

9. Glucose 1-phosphate causes initial depression, but at $24 \mathrm{hr}$. a slight increase over the control occurs.

10. These findings are discussed in relation to the carbohydrate metabolism of skin.

We are indebted to Professor J. R. Squire for his continued interest and advice.

\section{REFERENCES}

Barker, J. B. \& Summerson, W. H. (1941). J. biol. Chem. 138, 535.

Barron, E. S. G., Meyer, J. \& Miller, Z. B. (1948). J. invest. Derm. $11,97$.

Bullough, W. S. (1954a). Exp. Cell Res. 7, 176.

Bullough, W. S. (1954b). Exp. Cell Res. 7, 186.

Cruickshank, C. N. D. (1954). Exp. Cell Res. 7, 374.

Cruickshank, C. N. D. \& Trotter, M. D. (1956). Biochem. J. 62, 57.

Field, J. (1948). Methods in Medical Research, vol. 1, p. 299. Ed. by Potter, V. R. Chicago: The Year Book Publishers Inc.

Griesemer, R. D. \& Gould, E. (1954). J. invest. Derm.22, 299.

Nelson, N. (1944). J. biol. Chem. 153, 375.

Randle, P. J. (1954). Brit. med. J. 1, 1237.

Reynold, A. E. \& Horn, G. W. (1955). Amer. J. Med.19, 163.

Roe, J. H. (1934). J. biol. Chem. 107, 15.

Slein, M. W., Cori, G. T. \& Cori, C. F. (1950). J. biol. Chem. 186, 763.

Somogyi, M. (1952). J. biol. Chem. 195, 19.

Thompson, R. H. S. (1946). Biochem. J. 40, 525.

\title{
The Origin of Melezitose: a Biochemical Relationship between the Lime Tree (Tilia spp.) and an Aphis (Eucallipterus tiliae L.)
}

\author{
BY J. S. D. BACON* AND BRENDA DICKINSON \\ Department of Biochemistry, University of Sheffield
}

\section{(Received 23 October 1956)}

The trisaccharide melezitose [O- $\alpha$-D-glucopyranosyl- $(1 \rightarrow 3)$ - $\beta$-D-fructofuranosyl- $(2 \rightarrow 1) \quad \alpha$-D-glucopyranoside] was first recognized as a new sugar by Bonastre (1833), who found it in a crystalline deposit called 'manna of Briançon', occurring on the

* Present address: Department of Biochemistry, Macaulay Institute for Soil Research, Aberdeen. branches of the larch (Larix spp.; French, "le mélèze'). It was later found in a number of other mannas and honeydews (listed by Hudson, 1946), notably that from Tashkent and the Middle East, called 'turanjabin'. Using material from the latter source Berthelot (1859), Alekhine (1889) and Tanret (1906) elucidated the main features of its 